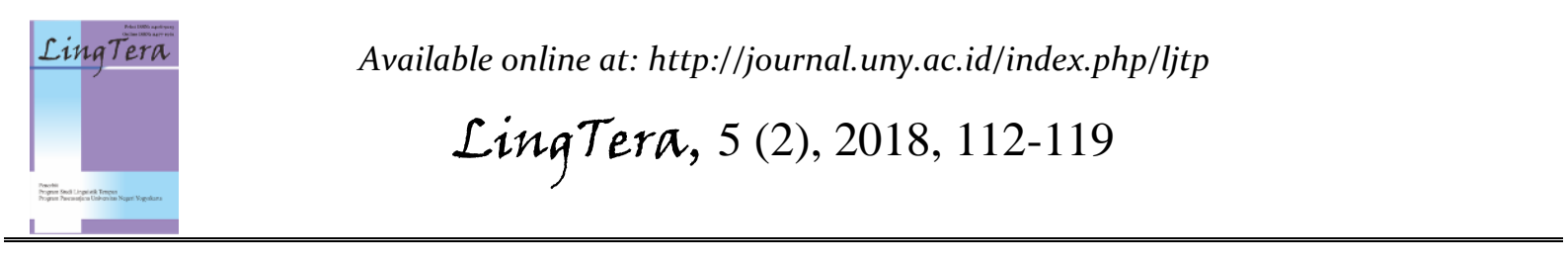

\title{
Developing extensive reading supplementary materials for XI grad students at madrasah
}

\author{
Mia Midianti Nurmalia ${ }^{1 *}$, Widyastuti Purbani ${ }^{2}$ \\ ${ }^{1}$ UPT Pusat Bahasa, Institut Teknologi Bandung. Gedung CADL Lantai 1, Jalan Ganesha No. 10, Lb. \\ Siliwangi, Coblong, Kota Bandung, Jawa Barat 40132, Indonesia \\ ${ }^{2}$ Department of English Education, Program Pascasarjana, Universitas Negeri Yogyakarta. \\ Jalan Colombo No. 1, Karangmalang, Yogyakarta, 55281, Indonesia \\ * Corresponding Author. Email: miamidianti@gmail.com \\ Received: 23 October 2017; Revision: 6 August 2018; Accepted: 31 December 2018
}

\begin{abstract}
This research aimed to develop reading supplementary materials and to verify the appropriateness of the materials to support the learning process of the grade XI students at Madrasah Aliyah Al Ma'Had An-Nur. This research was a research and development study. The results of the research are as follows. First, this research produced a set of extensive reading supplementary materials. Second, the results of material validation by material and graphic designer experts, the try-outs by grade XI students, and the perception of the English teacher showed that the extensive reading supplementary materials were considered appropriate to be applied in English class.
\end{abstract}

Keywords: extensive reading, supplementary learning materials

How to Cite: Nurmalia, M., \& Purbani, W. (2018). Developing extensive reading supplementary materials for XI grad students at madrasah. LingTera, 5(2), 112-119. doi:https://doi.org/10.21831/lt.v5i2.16510

https://doi.org/10.21831/lt.v5i2.16510

\section{INTRODUCTION}

In any language class, reading was one of the most important activities, not only as a source of information, but also as a means in consolidating and extending one's knowledge of the language (Rivers, 1981, p.80). Through reading skill, the students can improve their understanding and knowledge of the language.

There were two techniques of reading namely intensive reading and extensive reading. Intensive reading meant reading with concentration and great care in order to understand exactly the meaning of a written text. Meanwhile, extensive reading was an approach to language teaching in which learners read a lot of easy material in the new language (Arnold, 2009; Brown, 2015, p.54).

Extensive reading helped to build learners' vocabulary, to introduce them to words and language chunks that may not be covered in short texts, to give them a sense of common word partnership, and to develop their understanding of grammar by allowing them to see all sorts of grammatical structures in use (Day \& Bamford, 1998, p.21).
Reading was thought to be a crucial skill in EFL learning process, and extensive reading was a very useful strategy (de Morgado, 2009, p.3139). The aim of extensive reading was to build reading fluency, not necessarily to learn new things (although they may learnt some), and to deepen their knowledge of already met language items and to get a better sense of how these fit together communicatively. (Nutall, 1996, p.84). This allowed the learners to process language faster and to improve comprehension and enjoyment.

There were many benefits to be gained indirictle by employing extensive reading approach as stated by Day and Bamford (1988, p.96-97). First, extensive reading develops learner autonomy. It could be done anywhere, at any time of the day. Second, extensive reading offered comprehensible input. Third, extensive reading enhanced general language competences. Fourth, extensive reading helped improve writing. There was a well-established link between reading and writing. The reading habit can influence and help students in writing narrative texts (Mansor, Rasul, Rauf, \& Koh, 2013; Pao, 2016, p.124) The 


\section{LingTera, 5 (2), 2018 - 113}

Mia Midianti Nurmalia, Widyastuti Purbani

benefits of extensive reading extended beyond reading.

Various texts can be used as extensive reading materials for the students. They can be included as learning materials. Every teaching and learning process required learning materials. They become the guidance for the teachers and the students to accomplish the classroom activities. Students were unable to achieve the learning objectives properly without any learning materials. It was very important for every school to provide the students with sufficient materials.

One of the schools that required sufficient materials, specifically extensive reading materials, was Madrasah Aliyah Al Ma'Had An-Nur. It was a private Islamic senior high school located in Sewon, Bantul, Yogyakarta. Based on the preliminary interview and preliminary observation with the students and the English teachers, it was found that the teachers used photocopied reading materials extracted from several textbooks as the main source of reading learning materials. The texts were mainly common Indonesian folklores which the students already knew and familiar with the story. Thus, the lack of variation made the students uninterested in reading the texts. Their statement was supported by the result of need analysis. The students should be provided with various reading materials that met their learning needs. However, there was no need to substitute the main reading materials from the teachers.

The problems of learning English reading at Madrasah Aliyah Al Ma' Had An-Nur in terms of materials were identified as follows. First, there were no extensive reading supplementary materials for XI grade students at Madrasah Aliyah Al Ma'Had An-Nur. Second, the currents materials had little variation of texts they were only extracted from several textbooks. Third, lack of variation of the texts made the students uninterested in reading English texts.

Having considered the indentification of the problems, this study only focused on the problem about the lack of variation of the texts to support the teaching and learning process in the English class. Thus, this research study was conducted to develop extensive reading supplementary materials. The materials were designed in form of printed materials. In addition, the contents of the materials were adjusted to the students' target needs and learning needs.

The characteristics of the materials developed are described as follows. First, the materials were designed in the form of printed materials. Second, the materials only consist of six chapters. Third, the materials were designed only for reading skill. Fourth, the materials were designed to be supplementary materials for the students to support their learning process. Last, the materials were developed in accordance with the students' needs.

This study expected to contribute something useful for some parties including the students, the teachers and the educational institution. The product of this study can be utilized as learning materials for students. The materials also can be used by the teachers during the teaching process. For the educational institution, the product of this study can be implemented in the school where the research was conducted.

This research and development study was conducted based on several assumptions that there is English subject taught at Madrasah Aliyah Al Ma'Had An-Nur and there are no appropriate supplementary reading materials which can be used in teaching and learning English through the English subject. However, this study have several limitations; the materials were not designed for teaching all four language skills (listening, speaking, reading, and writing), the supplementary materials were proposed to utilized for the classroom process only within one semester, and the materials try-outs were only conducted in one selected senior high school.

\section{METHOD}

In conducting this research study, the researcher applied Research and Development $(\mathrm{R}$ $\&$ D) as the research design proposed by Borg \& Gall (2007). This R \& D design covered a set of stages which is used as the foundation of the study. This research started from needs assessment, then materials were developed to meet specific needs and according to the detailed specifications. Once accomplished, the product was validated by relevant experts and revised. Then, the validated product was tried-out in a small scale and revised based on the results. In this case, the criteria of success are surely needed to determine the acceptability of the product.

This research study was conducted from October 2016 to July 2017 at Madrasah Aliyah Al Ma'Had An-Nur. The needs analysis was conducted on October 17, 2016. Then, the tryouts was conducted for two days on June 15, 2017 and June 16, 2017. Later, the researcher took additional interviews after try-outs with the students and the English teacher. After the materials were revised, the researcher visited the 


\section{LingTera, 5 (2), 2018 - 114}

Mia Midianti Nurmalia, Widyastuti Purbani

school again to give the materials to the English teacher.

This research study employed try-outs. They were conducted to find out the appropriateness of the product for the participants. The subjects of this research were the XI grade students at Madrasah Aliyah Al Ma'Had An-Nur. They were 28 students from XI IPA 2 who were involved in filling the questionnaires for needs analyisis and conducting try-outs for the product.

As mentioned previously, this research study applied Research and Development (R \& D) design. In applying this design, the researcher adapted two research procedures. The first procedure was proposed by Gall, Gall, \& Borg (2007, p.602) namaly $\mathrm{R} \& \mathrm{D}$ cycle. The major steps in the cycle were presented as follows; (1) Research and collecting information, (2) Planning, (3) Developing preliminary form of the product, (4) Preliminary field testing, (5) Preliminary product revision, (6) Main field testing, (7) Operational product revision, (8) Operational field testing, (9) Field product revision, (10) Dissemination and implementation.

The second procedure was recommended by another expert, Hitomi Masuhara, namely linear Model X (Tomlinson, 1998, p.247). This research procedure followed in this study was the combination of R \& D model proposed by Borg $\&$ Gall and the linear Model X recommended by Masuhara that has been modified.

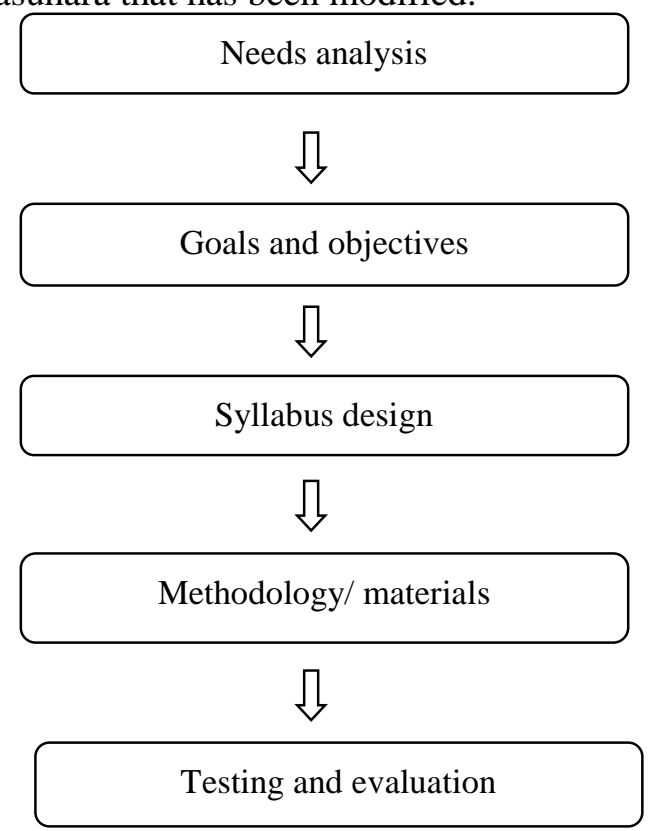

Figure 1. Model X - Course Design Procedures

The modification of those two models was applied to design the product of this research and development study. It was necessary to apply this modified model because both models contain cycles that complete each other. In addition, the modification of the two combined models offers more adequate and complete steps so that it enables the researcher to conduct the research more sufficiently. The detailed steps of the modification can be seen in the Figure 2.

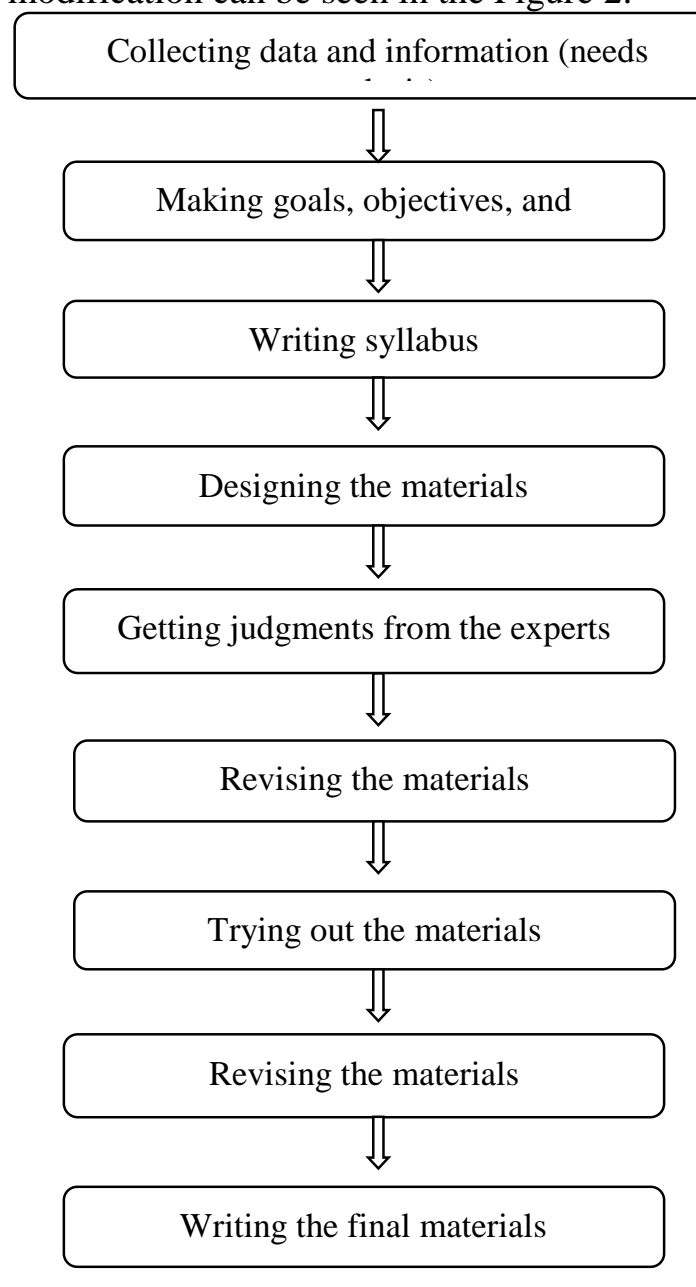

Figure 2. The Research Procedure

The researcher was suggested by the headmaster to conduct the research to XI grade students, since they were already settled down as students at Madrasah Aliyah Al Ma'Had An-Nur. The first step to accomplish was collecting data and information with questionnaires, interviews, observation, and literary review. In order to conduct a need analysis as the primary procedure in developing a learning materials, questionnaires were distributed to the XI grade students of Madrasah Aliyah Al Ma'Had An-Nur to identify their target needs and learning needs. The results of the qustionnaires were subsequently considered to determine the goals and the learning objectives.

The second way to collect the data was by interviewing some parties. They referred to the 


\section{LingTera, 5 (2), 2018 - 115}

Mia Midianti Nurmalia, Widyastuti Purbani

XI grade students of Madrasah Aliyah Al Ma'Had An-Nur. The results of the interview was used to strengthen the previous data gained from the questionnaires.

The third way to collect the data was through observation. In this research, the process was conducted by directly observing the teaching and learning process during the English class at Madrasah Aliyah Al Ma'Had An-Nur attended by the XI grade students. The researcher gathered all necessary information from the observation to support and complete the previous data gained from the questionnaires and interviews.

The last way to collect data was by reading supporting sources such as books, journals, and thesis or dissertations. All information and theories from the sources that enable to strengthen and to support the issue in this research study were included as well.

The second step of research procedure was determining goals and learning objectives. The two were determined by considering the result of the needs analysis referring to the students' target needs and learning needs from the data gained previously. The two components were also prominently required to make the learning materials clear about the reason why the learning materials were necessary to be developed.

The third step was to design the syllabus. The syllabus covered description of the content of the learning materials. The description included chapter titles, skill, theme, text type, basic competence(s), goals, materials, key vocabulary, and activities.

Having designed the syllabus, the next step was designing the materials. Since the materials only focused on reading, the researcher only included any subject matters that belonged to reading aspects. The materials comprised of six chapters. Each chapter contained topics that most of the students preferred.

The fifth step to conduct was getting judgments from the experts. The learning materials were necessary to be judged and evaluated by experts. It was intended to acquire judgments that the materials were appropriate to be delivered to the learners.

The sixth step to conduct was revising the materials. Some corrections and recommendations from the experts were considered to make the materials better. The evaluation was necessary to measure whether the materials were already proper or not to be implemented. Since the materials would be implemented in the real process, they should contain proper subject matters that could really support the students to require useful knowledge and skill.

The seventh step to conduct was trying out the materials. The try-outs were conducted at Madrasah Aliyah Al Ma'Had An-Nur. They involved 28 students of XI IPA 2. The try-outs were purposely conducted to gain some information particularly in line with the appropriateness of the material with the students' needs.

The next step was revising the materials. They were once again revised after the try-out. It is necessary to do because there would be some comments or recommendations from the participants.

Finally, the last step was writing the final materials. All recommendations and some corrections were included to complete the final learning materials. Some suggestions from the experts and the participants were considered as well. Therefore, the materials could be implemented appropriately during the teaching and learning process.

\section{Instruments and Techniques of Data Collection}

This research study utilized some instruments and collected two kinds of data; quantitative and qualitative. The quantitative data were collected through questionnaires. The questionnaires employed to obtain data covered the need analysis questionnaires, experts' judgments questionnaires, and try-out questionnaires. The details were presented as follows. First, the needs analysis questionnaires were distributed to the students in the beginning of the research. The results then were used to design the learning materials.

Second, the experts' judgments questionnaires were addressed to the experts who can help to validate and judge the appropriateness of the developed materials. The experts referred to a learning materials expert and graphic design expert.

Third, the try-outs questionnaires were distributed to the students and the English teacher to gain any information about the appropriateness of the learning materials implemented.

Besides employing some questionnaires, the researcher also conducted some interviews and observations. The interviews were addressed the several XI grade students that belong to the subject of the research. Meanwhile, the researcher conducted the observation by directly visiting the school, in this case, Madrasah Aliyah 


\section{LingTera, 5 (2), 2018 - 116}

\section{Mia Midianti Nurmalia, Widyastuti Purbani}

Al Ma'Had An-Nur, and observing the teaching and learning process in the English class.

Techniques of Data Analysis

The data were analyzed both quantitatively and qualitatively. The results of the questionnaires were analyzed quantitatively by utilizing descriptive statistics while some data gained from the results of the interviews and observation were analyzed qualitatively. The raw data in the form of number then interpreted in qualitative sense. Each indicator is followed by five answers with ranges from very negative to very positive: 5 for 'very good', 4 for 'good', 3 for 'fair', 2 for 'poor', and 1 for 'very poor'. The formulation was explained as follows.

$\mathrm{X}$ : Average score

$\sum X$ : Total score

$\mathrm{N}$ : Total Respondent

$$
\bar{X}=\frac{\sum \mathrm{X}}{n}
$$

Having obtained the total score, the category is determined in the Table 1 .

Table 1. Scoring of Questionnaire Form

\begin{tabular}{ccc}
\hline Formula & $\begin{array}{c}\text { Interval } \\
\text { Score }\end{array}$ & Category \\
\hline$X i+1.8 S B_{i}<\mathrm{X}$ & $4.20<\mathrm{X}$ & $\begin{array}{c}\text { Very } \\
\text { Good }\end{array}$ \\
& & Good \\
$X i+0.6 S b_{i}<\mathrm{X} \leq \mathrm{Xi}+$ & $3.40<\mathrm{X}$ & $\leq 4,20$ \\
$1.8 S b_{i}$ & & Fair \\
$X i-0.6 S b_{i}<\mathrm{X} \leq \mathrm{Xi}$ & $2.59<\mathrm{X} \leq$ & \\
$+0.6 S b_{i}$ & 3.40 & \\
$X i+1.8 S B_{i}<\mathrm{X} \leq \mathrm{X}-$ & $1.79<\mathrm{X} \leq$ & Poor \\
$0.6 S b_{i}$ & 2.59 & \\
$X \leq X i-1,8 S b_{i}$ & $0<\mathrm{X} \leq 1.79$ & Very Poor \\
\hline
\end{tabular}

(Sukardjo, 2008, p.35)

\section{RESULT AND DISCUSSION}

The process of this research began with conducting the needs analysis. The questionnaires of the needs analysis were distributed to the 28 XI IPA 2 students of Madrasah Aliyah Al Ma'Had An Nur. The needs analysis conducted in this research study covers two indicators; target needs and learning needs.

Based on the data analysis, the students ${ }^{6}$ necessity in learning reading skill, obstacles in learning reading, wants, and needs, it can be concluded; (1) The XI grade students at Madrasah Aliyah Al Ma'Had An Nur were in the level of beginner in English proficiency, (2) The reading skills that the students' need were reading activity, reviewing, pre-reviewing topic, scaning, and skimming, (3) The obstacles of the students in learning reading were the lack of understanding the vocabulary and the language of the text was too complicated, (4) The students expected to enrich their vocabulary and to be able to read English text better by learning the supplementary materials, (5) The students preferred to read the text first, then to analyze it, and to do task lastly, (6) The students preferred different materials and different texts from the primary textbooks, (7) The students preferred the text themes such as art \& literature, biography, entertainment, and poem or lyrics, (8) The students preferred the supplementary materials in form of printed materials, (9) The students preferred question and answer, matching words or sentences, and word puzzle as reading tasks, (10) The students preferred to self read the tasks and to do the tasks individually.

Based on the teacher's interview, it can be concluded that the primary reading materials were already sufficient with the students' English proficiency, however they lacked of text variation. The teacher supported the researcher to develop extensive reading supplementary materials for the students to give them more various reading materials.

In developing extensive reading supplementary materials, the researcher also used literatures to support and to serve as sources in constructing the materials. The literatures are; (1) Extensive Reading in the Second Language Classroom by Day \& Bamford (2004), Materials Development in the Language Teaching by Tomlinson (1998), and Teaching Reading Skills in a Foreign Language by Nutall (2006), to name a few.

\section{Product Development}

The next step to carry out after conducting the needs analysis was developing the syllabus. It comprised the number of chapters, skill, theme, text type, basic competence(s), goals, materials, key vocabulary, and activities. The number of chapters indicated the total chapters in the supplementary materials. There were six chapters with different themes/topics. The skill dealt with reading skill, which was the main and the only skill that developed in the supplementary materials. The text type in the materials dealt with several reading texts provided in the materials, they are; review, report, biography, procedure, and poem. The basic competence(s) were skills acquired by students in relation to the learning targets and objectives. The goals were purposely designed to identify the students' understanding 
of the materials being learned in the classroom. The key vocabulary in each chapter referred to a list of vocabulary provided to enable students to enrich their vocabulary and broaden their knowledge of English language. The activities in the materials covered a series of activity the students would accomplish during the learning process.

There were six chapters developed as learning materials; (1) movie time, (2) the origin of the newspapers, (3) Diana, the people's princess, (4) the danger of being stubborn, (5) a poem, and (6) books to read.

Each chapter included several tasks which were designed only to support the students' reading skill. The organization of all chapters consisted of three parts; first is the text, second is the additional information of the text, and the last is the activities.

After developing the materials, they had to be validated by the two experts; material expert and graphic design expert. The material expert was a lecturer of Yogyakarta State University and the graphic design expert was a graphic designer at a Diandra Creative Publishing Yogyakarta.

There were four aspects of appropriateness that needed to be validated namely content aspect, language aspect, task/activity aspect, and graphic design aspect.

According to the results of the validation, the materials got the score in the range of 3.77 to 4.00 on the scale 0 to 5 , with the average score of 3.94. It was belonged to the good category. Thus, the materials were appropriate to be tried-out to the XI grade students of Madrasah Aliyah Al Ma'Had An Nur. The details of the validation results can be seen in the Table 2 .

Table 2. Analysis of Validation Results

\begin{tabular}{ccccc}
\hline No. & \multicolumn{1}{c}{$\begin{array}{c}\text { Scoring } \\
\text { Aspects }\end{array}$} & Score & $\begin{array}{c}\text { Average } \\
\text { Score }\end{array}$ & Category \\
\hline 1. & Content Aspect & 4.00 & 3.94 & Good \\
2. & $\begin{array}{l}\text { Language } \\
\text { Aspect }\end{array}$ & 4.00 & & \\
3. & $\begin{array}{l}\text { Task/Activity } \\
\text { Aspect }\end{array}$ & 4.00 & & \\
4. & $\begin{array}{l}\text { Graphic Design } \\
\text { Aspect }\end{array}$ & 3.77 & & \\
\hline
\end{tabular}

The next process after validating the supplementary materials was try-out. The try-out was conducted at Madrasah Aliyah Al Ma'Had An Nur on 15-16 of June 2017. The subjects of the try-out were the 28 students of XI IPA 2 at Madrasah Aliyah Al Ma'Had An Nur. The students were asked to choose the chapters by themselves, then they had to swap the chapters with their friends, it meant that all of the students experienced the six chapters of the product. While the students interacted with the product, the researcher assisted them.

After that, the questionnaires about the product were distributed to the students as an evaluation to the researcher. There were four aspects of appropriateness that needed to be evaluated namely the content aspect, the language aspect, the task/activity aspect, and the graphic design aspect. The students needed to fill the questionnaires by each chapter.

Based on the score given by the students, the supplementary materials got the score in the range of 3.96 to 4.10 on the scale 0 to 5.00 . The average score was 4.01 (good). Thus, the supplementary materials belonged to the good category and they were appropriate for the XI grade students at Madrasah Aliyah Al Ma'Had An Nur. The details of the try-out results can be seen in the Table 3.

Table 3. Analysis of Try-Out Results

\begin{tabular}{ccccc}
\hline No. & $\begin{array}{c}\text { Scoring } \\
\text { Aspects }\end{array}$ & Score & $\begin{array}{c}\text { Average } \\
\text { Score }\end{array}$ & Category \\
\hline 1. & Content Aspect & 4.10 & 4.01 & Good \\
2. & Language & 4.00 & & \\
& Aspect & & & \\
3. & Task/Activity & 4.00 & & \\
& $\begin{array}{l}\text { Aspect } \\
\text { 4. }\end{array}$ & & & \\
& Graphic Design & 3.96 & & \\
\hline
\end{tabular}

Table 4. Analysis of the Teacher's Perception

\begin{tabular}{llccc}
\hline No. & $\begin{array}{c}\text { Scoring } \\
\text { Aspects }\end{array}$ & Score & $\begin{array}{c}\text { Average } \\
\text { Score }\end{array}$ & Category \\
\hline 1. & Content Aspect & 4.40 & 4.05 & Good \\
2. & $\begin{array}{l}\text { Language } \\
\text { Aspect }\end{array}$ & 4.16 & & \\
3. & Task/Activity & 3.66 & & \\
& $\begin{array}{l}\text { Aspect } \\
\text { 4. }\end{array}$ & & \\
& Araphic Design & 4.00 & & \\
\hline
\end{tabular}

In order to obtain English teacher's assessment toward the learning materials, the teacher was provided with evaluation sheet. This evaluation sheet was designed to enable the teacher to evaluate the four aspects of appropriateness namely the content aspect, the language aspect, the task/activity aspect, and the graphic design aspect. According to the teacher's evaluation, the supplementary materials got the score in the range of 3.66 to 4.40 on the scale 0 to 5 , with the average score of 4.05 . Thus, the supplementary materials belonged to the good category and 


\section{LingTera, 5 (2), 2018 - 118}

Mia Midianti Nurmalia, Widyastuti Purbani

considered appropriate to be implemented as learning materials for XI grade students at Madrasah Aliyah Al Ma'Had An-Nur. The details of the teacher's perception can be seen in the Table 4.

\section{Last Product Revision}

The extensive reading supplementary materials consisted of six chapters. Each chapter covered several tasks. Chapter 1 consisted of 5 tasks, chapter 2 consisted of 5 tasks, chapter 3 consisted of 4 tasks, chapter 5 consisted of 4 tasks, and chapter 6 consisted of 4 tasks. In terms of goal, the supplementary materials were designed to provide students with various reading texts that suitable with their English proficiency and as XI grade students at Madrasah Aliyah Al Ma'Had An-Nur.

In terms of input, the supplementary materials included instructions, various texts, and pictures/images/illustrations that the students regarded as comprehensible. It was necessary to include comprehensible inputs in learning materials in order to enable the students to learn the target language easier.

The materials also included various themes/topics that appropriate for the XI grade students of Madrasah Aliyah Al Ma'Had An-Nur. It was necessary to include various themes/topics that were interesting and familiar to the students because they could motivate the students to learn the target language.

The materials included tasks that were put in a similar order for all chapters. The tasks were arranged sequentially from introduction activities to the main activities.

The activities began with asking the students about a particular topic to arouse their curiosities. Then, the students read the texts and did the main activities i.e. answering questions related to the text. The tasks were arranged sequentially form the easiest to the most difficult ones. It was considered as an effective way to motivate the students to learn the target language.

In relation to procedure, the students selfread the texts and did the tasks/activities by themselves. In terms of role, the developed materials provided the students with tasks that enable them to participate in the learning process actively. The teacher acted as a facilitator to the students. Finally in terms of setting, the materials were arranged to be learned in the classroom.

\section{Discussion of the Final Product}

In correlation with the theory of extensive reading, the supplementary materials fulfilled the 10 characteristics of extensive reading proposed by Richard Day (Day \& Bamford, 1998, p.11). The characteristics were; (1) Students read large amounts of printed materials, (2) A variety of reading material on a wide range of topics was available, (3) Learners chose what they want to read, (4) Learners read as much as possible, (5) The purpose of reading was usually related to pleasure, information, and general understanding, (6) Reading was its own reward, (7) Reading speed was usually faster than slower, (8) Reading was individual and silent, (9) Teachers oriented and guided their students, (10) The teacher was a role model of a reader.

The extensive reading supplementary materials for XI grade students of Madrasah Al Ma'Had An-Nur provided six different texts with different themes and topics included in six chapters. The students also freely chose the chapter by themselves, since the product is in form of loose printed materials. The texts were carefully selected to suit the students' English proficiency level, which was on the beginner level. The language and the vocabulary of the texts also suitable to the students, and the materials provided glossary box for students to enrich their new vocabulary. In tasks/activities, the students did the tasks/activities individually and they also self-read the texts. The teacher acted as a facilitator for the students.

However, there are some limitations in conducting the research as follows; (1) The product only covered reading skill, (2) The tryouts of the six chapters were conducted in two meetings, although each chapter was not designed to be accomplished by the students in one meeting, and (3) The researcher did not measure the effectiveness of the product due to the limited time.

\section{CONCLUSION}

Considering the students' target needs and learning needs, the appropriate extensive reading supplementary materials for XI grade students at Madrasah Aliyah Al Ma'Had An-Nur were presented as follows. In relation to the reading skills, the supplementary materials provided the reading activity skill, the reviewing skill, the prereviewing topic skill, the scanning skill, and the skimming skill. In relation the inputs, the materials included various text themes/topics, i.e. 
Mia Midianti Nurmalia, Widyastuti Purbani

art \& literature, biography, entertainment, and poem/lyrics. The materials were in form of printed materials consisted of six chapters. The materials also included various tasks/activities that suitable with the students' English proficiency level. The students acted as active participants in the learning process. They self-read the texts and did the tasks/activities individually in the classroom. Meanwhile, the teacher acted as a facilitator to the students during the learning process.

Based on the try-outs, the supplementary materials acquired the average score of 4.01 on the scale 0 to 5 which categorized as good. Therefore, the extensive reading supplementary materials were considered appropriate for XI grade students of Madrasah Aliyah Al Ma'Had An-Nur.

\section{REFERENCES}

Arnold, N. (2009). Online extensive reading for advanced foreign language learners: An evaluation study. Foreign Language Annals, 42(2), 340-366.

Brown, D. (2015). Teaching by principles: an interactive approach to language pedagogy (4 $4^{\text {th }}$ edition). Upper Saddle River: Pearson.

Day, R. \& Bamford, J. (1998). Extensive reading in the second language classroom. Cambridge: Cambridge University Press. de Morgado, N.F. (2009). Extensive reading: students' performance and perception. The Reading Matrix, 9(1) 31-39.

Gall, M. D., Gall, J. P., \& Borg, W. R. (2007). Educational research: an introduction ( $8^{\text {th }}$ edition). Boston: Allyn \& Bacon.

Mansor, A. N., Rasul, M. S., Rauf, R. A. A., \& Koh, B. L. (2013). Developing and sustaining reading habit among teenagers. The Asia-Pacific Education Researcher, 22(4), 357-365.

Nutall, C. (1996). Teaching reading skills in a foreign language. Oxford: MacMillan Heinemann the English Language Teaching.

Pao, B. (2016). The influence of reading habit and grammar knowledge on the students' capability of writing narrative texts. LingTera, $\quad 3(2), \quad 122-129$. doi:http://dx.doi.org/10.21831/lt.v3i2.111 10

Rivers. W.M. (1981). Teaching foreign language skills. Chicago: The University of Chicago Press.

Sukardjo. (2008). Buku pegangan kuliah evaluasi pembelajaran. Sleman: Universitas Negeri Yogyakarta.

Tomlinson, B. (1998). Materials development in language teaching. Cambridge: Cambridge University Press. 